Int. J. Electrochem. Sci., 15 (2020) 10785 - 10801

International Journal of

ELECTROCHEMICAL

SCIENCE

WWW.electrochemsci.org

\title{
Potentiometric Study of a New Schiff Base and its Metal Ion Complexes: Preparation, Characterization and Biological Activity
}

\author{
Hamed M. Al-Saidi ${ }^{1}$, Gamal A. Gouda ${ }^{2, *}$ and O. A. Farghaly ${ }^{2}$ \\ ${ }^{1}$ Chemistry Department, University College in Al-Jamoum, Umm Al-Qura University, 21955, \\ Makkah, Saudi Arabia \\ ${ }^{2}$ Faculty of Science, Al-Azhar University, Assiut Branch, 71524 Assiut, Egypt. \\ *E-mail: ggouda73@azhar.edu.eg
}

doi: $10.20964 / 2020.11 .06$

Received: 18 July 2020 / Accepted: 3 September 2020 / Published: 30 September 2020

Some metal complexes of a new Schiff base [4-(morpholin-4-yl)benzylidenyl]thiosemicarbazide (L) have been investigated. A potentiometric method was used to determine their stability constants by $\mathrm{pH}$-metric titration. The stoichiometric protonation constants of $\mathrm{L}$ in $25 \%(\mathrm{v} / \mathrm{v})$ ethanol-water mixture and ionic strength of $1 \mathrm{~mol} \mathrm{dm}^{-3}$ were found to be 4.88 and 10.21. The formation constants of the complexes increase in the order of $\mathrm{La}$ (III) $>\mathrm{Fe}$ (III) $>\mathrm{Co}$ (II) $>\mathrm{Cu}$ (II) $>\mathrm{Mn}$ (II) $>\mathrm{Pd}$ (II) $>\mathrm{Ni}$ (II) ions. The chemical structure of $\mathrm{L}$ and its metal complexes were established using elemental analyses and infrared spectroscopy. The microanalytical data reveals that a 1:1 (metal:ligand) stoichiometric ratio was found for the compounds. The geometric parameters of the metal-L complexes were assumed according to the density functional theory (DFT) method. The complexes show a moderate antibacterial inhibition against Staphylococcus aureus and Escherichia coli and a fair degree of antifungal activity against Aspergillus fumigatus, Alternaria alternata and Fusarium oxysporum.

Keywords: Potentiometric, new Schiff base, metal complexes, theoretical studies, antimicrobial activity.

\section{$\underline{\text { FULL TEXT }}$}

(C) 2020 The Authors. Published by ESG (www.electrochemsci.org). This article is an open access article distributed under the terms and conditions of the Creative Commons Attribution license (http://creativecommons.org/licenses/by/4.0/). 